\title{
Identifikasi Faktor yang Memengaruhi Partisipasi Masyarakat Kampung Ketandan sebagai Kampung Wisata di Surabaya
}

\author{
Maghfirah B. Muwifanindhita dan Hertiari Idajati \\ Departemen Perencanaan Wilayah dan Kota, Fakultas Arsitektur Desain dan Perencanaan, \\ Institut Teknologi Sepuluh Nopember (ITS) \\ e-mail: hertiari_idajati@urplan.its.ac.id
}

\begin{abstract}
Abstrak-Kampung Ketandan sebagai salah satu kampung wisata di Surabaya yang berada di tahap perintisan disiapkan untuk bisa menjadi destiasi wisata yang berdampingan dengan pengembangan kawasan heritage koridor Tunjungan. Namun partisipasi masyarakat Kampung Ketandan dalam mewujudkan kampung wisata masih terbilang kurang. Partisipasi masyarakat yang masih kurang tersebut dipengaruhi oleh faktor-faktor yang perlu diketahui sehingga, pengembangan kampung wisata dapat berjalan secara berkelanjutan. Penelitian ini dilakukan untuk mengidentifikasi faktor yang memengaruhi partisipasi yang diberikan masyarakat Kampung Ketandan dengan melakukan in-depth-interview pada stakeholder terpilih. Kemudian dilakukan konten analisis pada transkrip hasil wawancara untuk menggali faktor yang memengaruhi partisipasi masyarakat dalam penciptaan kampung wisata di Kampung Ketandan. Hasil dari penelitian ini mengindikasi bahwa dari sepuluh sub-faktor yang diujikan, hanya sub-faktor pendidikan yang tidak berpengaruh terhadap kondisi partisipasi masyarakat, serta ditemukan faktor baru sebagai faktor lokal yang memengaruhi partisipasi masyarakat Kampung Ketandan dalam mewujudkan kampung wisata yaitu faktor pendapatan, faktor penggerak, faktor karakter masyarakat, dan faktor moral.
\end{abstract}

Kata Kunci-Kampung Ketandan, kampung wisata, faktor partisipasi

\section{PENDAHULUAN}

$\mathrm{K}$ AMPUNG sebagai ciri khas dari Indonesia, ditandai dengan ciri kehidupan yang terjalin dalam ikatan kekeluargaan yang erat [1]. Ikatan kekeluargaan tersebut merupakan kesatuan manusia yang dalam aplikasinya mencirikan interaksi antar warganya. Interaksi yang hadir pada sebuah kampung juga bergantung dari adat istiadat yang ada, norma-norma hukum yang disepakati, dan aturan khas yang mengatur seluruh pola tingkah lakunya [2]. Di kawasan perkotaan, kampung yang masih mempertahankan kearifan lokalnya dapat dikatakan unggul pada aspek sosial-budaya. Nilai-nilai budaya yang terwujud dalam keseharian masyarakat kampung membuat daya tarik tersendiri bagi masyarakat di tengah suasana hiruk-pikuk perkembangan kota. Dengan masih dijaganya nilai-nilai budaya serta kearifan lokal, kampung kota berpotensi menjadi daya tarik wisata.

Destinasi wisata berupa kampung kota merupakan salah satu daya tarik wisata di Surabaya, dengan ditetapkannya lima kampung kota baru pada tahap perintisan. Kampung wisata yang masuk dalam tahap perintisan antara lain Kampung Ketandan, Kampung Nelayan Kenjeran, Kampung Dolly, Kampung Semanggi di Sememi serta pengembangan kampung tematik baru [3]. Dari lima kampung yang sedang dikembangkan, Kampung Ketandan memiliki keunikan dan potensi yang tidak dimiliki kampung lainnya. Lokasi Kampung Ketandan yang terletak di kawasan emas Surabaya dengan tingginya nilai ekonomi dan letaknya yang strategis menjadi keunikkan tersendiri. Adanya alokasi ruang disepanjang koridor Tunjungan sebagai kawasan wisata budaya kota pun membuktikan potensi Kampung Ketandan sebagai kampung kota berwawasan budaya [4].

Sebagai upaya pelestarian sejarah dan budaya yang ada, kampung kota perlu sebuah bentuk partisipasi masyarakat. Konsep pengembangan kampung kota menjadi daya tarik wisata juga dapat mengajak masyarakat sekitar dalam melestarikan sosial-budaya yang dijadikan sebagai produk unggulan kampung wisata budaya, sehingga berdampak pada peningkatan ekonomi masyarakat [5]. Proses perubahan dalam upaya meningkatkan kapasitas masyarakat, bergantung pada beberapa aspek, yaitu sosiologis, politik, ekonomi, psikologis, dan kultural. Aspek-aspek tersebut mengikuti proses yang diawali dari mengelola masalah sosial yang ada, memanfaatkan sumber daya dan peluang, sampai memenuhi kebutuhan masyarakat untuk mendapat kondisi yang lebih sejahtera. Dari tiga kondisi tersebut, tidak terlepas dari pada pengaruh masing-masing individu, seperti psikologis, adanya informasi, ketrampilan, teknologi, stratifikasi sosial, budaya, sampai kelembagaan yang mendukung serta pelayanan pemerintah [6].

Melihat kondisi fisik Kampung Ketandan yang berubah dapat menjadi alasan bahwa terdapat pastisipasi dari masyarakat Kampung Ketandan sebagai kampung wisata. Namun, partispasi masyarakat yang sudah ada akan terancam tidak berkelanjutan. Untuk itu dilakukan penelitian untuk mengidentifikasi faktor yang berpengaruh terhadap partisipasi masyarakat Kampung Ketandan dalam upaya peningkatan partisipasi masyarakat serta menjaga eksistensi kampung kota sebagai kampung wisata di Surabaya. 


\section{METODE PENELITIAN}

Penelitian ini bersifat kualitif dengan metode deskriptif eksploratif untuk mengidentifikasi faktor yang memengaruhi partisipasi masyarakat Kampung Ketandan sebagai kampung wisata.

Tabel 1

Kelompok Stakeholders Penelitian

\begin{tabular}{|c|c|c|c|}
\hline \multirow{3}{*}{$\begin{array}{l}\text { Stakeholders } \\
\text { Pemerintah }\end{array}$} & \multicolumn{2}{|c|}{ Posisi Stakeholders } & " Alasan Pemilihan \\
\hline & P1 & $\begin{array}{l}\text { Dinas } \\
\text { Pariwisata dan } \\
\text { Budaya Kota } \\
\text { Surabaya }\end{array}$ & 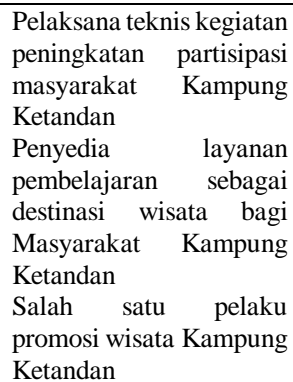 \\
\hline & $\mathrm{P} 2$ & $\begin{array}{l}\text { Badan } \\
\text { Perencanaan } \\
\text { Pembangunan } \\
\text { Kota Surabaya }\end{array}$ & $\begin{array}{l}\text { Perumusan kebijakan } \\
\text { perencanaan kota untuk } \\
\text { Kampung Ketandan } \\
\text { sebagai kampung wisata } \\
\text { Pengkoordinasian } \\
\text { perencanaan Kampung } \\
\text { Ketandan sebagai } \\
\text { kampung wisata }\end{array}$ \\
\hline Masyarakat & $\begin{array}{l}\mathrm{P} 3 \\
\mathrm{P} 4\end{array}$ & $\begin{array}{l}\text { Ketua RW } \\
\text { Ketua Karang } \\
\text { Taruna }\end{array}$ & $\begin{array}{lr}\text { Pelaku } & \text { dalam } \\
\text { peningkatan } & \text { partisipasi } \\
\text { masyarakat } & \text { Kampung } \\
\text { Ketandan } & \text { sebagai } \\
\text { Kampung Wisata }\end{array}$ \\
\hline
\end{tabular}

Sumber: Hasil analisis, 2018

Tabel 2.

Kriteria Pemilihan tiap Stakeholders

\begin{tabular}{lll}
\hline \hline Stakeholders & \multicolumn{1}{c}{$\begin{array}{c}\text { Posisi } \\
\text { Stakeholders }\end{array}$} & \multicolumn{1}{c}{ Kriteria Pemilihan } \\
\hline Pemerintah & $\begin{array}{l}\text { Dinas Pariwisata } \\
\text { dan Budaya Kota } \\
\text { Surabaya }\end{array}$ & $\begin{array}{l}\text { Pria/Wanita } \\
\text { Lama kerja di instansi terkait }>3 \\
\text { tahun } \\
\text { Ikut berpartisipasi dalam kegiatan } \\
\text { pengembangan kampung Ketandan }\end{array}$ \\
& & Surabaya \\
& & Pria/Wanita \\
& Badan & Lama kerja di instansi terkait $>3$ \\
& Perencanaan & tahun \\
& Pembangunan & Ikut berpartisipasi dalam kegiatan \\
& Kengembangan kampung Ketandan \\
& & Surabaya \\
& & Pria/Wanita \\
Masyarakatana & Kama tinggal di Kampung Ketandan \\
& Ketua RW & $>$ 20 tahun \\
& Ketua Karang & Usia minimal 25 tahun \\
& Taruna & Ikut berpartisipasi dalam kegiatan \\
& & pengembangan Kampung Ketandan \\
& & Surabaya \\
\hline \hline
\end{tabular}

\section{A. Teknik Pengumpulan Data}

Data-data penelitian ini didapat dengan melakukan wawancara kepada stakeholder terpilih melalui perpaduan teknik sampling stakeholder analysis dan purposive sampling secara in-depth-interview. Wawancara dilakukan pada stakeholder baik dari pemerintah maupun masyarakat yang terlibat dalam pengembangan Kampung Ketandan, sehingga proses dalam menggali faktor yang berpengaruh dapat sesuai.

Analisis stakeholders untuk pemerintah diawali dengan melihat tugas pokok dan fungsi dinas terkait, sedangkan untuk stakeholders dari masyarakat dipilih dengan melihat keterlibatannya dalam pengembangan Kampung Ketandan sejak ditetapkan sebagai kampung wisata. Kemudian dilakukan identifikasi terhadap kepentingan dan pengaruh dari kedua jenis stakeholder yang dapat dilihat pada Tabel 1 .

Selanjutnya, diberikan kriteria pemilihan responden untuk tiap kelompok stakeholders dengan teknik sampling purposive sampling. Dengan dipilihnya teknik sampling purposive sampling didasarkan pada peluang keterlibatan stakeholder serta diharapkan dapat memberikan sampel penelitian yang representatif dalam penelitian ini, guna mendapatkan responden sesuai tujuan yang diharapkan seperti pada Tabel 2 .

Sumber: Hasil analisis, 2018

\section{B. Variabel Penelitian}

Variabel penelitian yang digunakan untuk mengidentifikasi faktor-faktor yang memengaruhi partisipasi masyarakat Kampung Ketandan dapat dilihat pada Tabel 3.

Tabel 3.

Indikator dan Variabel Penelitian

\begin{tabular}{ll}
\hline \hline \multicolumn{1}{c}{ Indikator } & \multicolumn{1}{c}{ Variabel } \\
\hline Sosial & Parapan \\
& Strukturan Sosial \\
& Budaya lokal \\
Budaya & Pekerjaan \\
Ekonomi & Sarana berkumpul dan beratraksi \\
Sarana & Jaringan listrik \\
Prasarana & Lembaga pengelola \\
Kelembagaan & Pelayanan pemerintah \\
Kebijakan & Apresiasi pemerintah \\
Pemerintan & \\
\hline \hline
\end{tabular}

Sumber: Hasil analisis, 2018

\section{Teknik Analisis Data}

Data pada penilitian ini diolah dengan teknik konten analisis. Teknik konten analisis dipilih untuk menyusun kesimpulan dengan melihat hasil wawancara yang berisi pendapat responden terkait faktor yang memengaruhi partisipasi masyarakat Kampung Ketandan dalam mewujudkan kampung wisata. Proses diawali dengan pembuatan transkrip untuk tiap responden, yang dilanjutkan dengan pemberian coding dan pewarnaan pada setiap variabel untuk memudahkan analisis. Selanjutnya dilakukan tabulasi hasil coding tiap variabel untuk selanjutnya diintepretasi serta dijabarkan secara statistik deskriptif.

\section{HASIL DAN DISKUSI}

Partisipasi masyarakat Kampung Ketandan dalam penciptaannnya sebagai kampung wisata dipengaruhi oleh beberapa faktor. Faktor tersebut diidentifikasi dengan melihat hasil wawancara baik dari pemerintah dan tokoh masyarakat Kampung Ketandan. Faktor yang diidentifikasi merupakan faktor yang menyebabkan kondisi partisipasi masyarakat Kampung Ketandan saat ini. Berikut diberikan penjabaran hasil analisis faktor yang memengaruhi partisipasi masyarakat Kampung Ketandan sebagai kampung wisata.

\section{A. Faktor Sosial}

Faktor sosial ini memiliki tiga sub-faktor yang berperan sebagai variabel, yaitu struktur sosial masyarakat, harapan 
yang ada di masyarakat, dan latar belakang pendidikan masyarakat Kampung Ketandan.

Tabel 4.

Rekapitulasi Analisis untuk Struktur Sosial

\begin{tabular}{llll}
\hline \hline \multicolumn{1}{c}{ Pemerintah } & \multicolumn{1}{c}{ P2 } & \multicolumn{1}{c}{ M1 } & \multicolumn{1}{c}{ M2 } \\
\hline Partisipasi & Partisipasi & Partisipasi & Partisipasi \\
masyarakat & masyarakat & masyarakat & masyarakat \\
dipengaruhi & dipengaruhi & dipengaruhi & dipengaruhi dari \\
karena & karena & karena & kinerja pengurus \\
strukturnya & strukturnya & strukturnya & kampung \\
sebagai & sebagai kartar & sebagai kartar & \\
kartar & Partisipasi & Partisipasi & Partisipasi \\
& masyarakat & masyarakat & masyarakat \\
& dipengaruhi dari & dipengaruhi dari & dipengaruhi \\
& kinerja pengurus & kinerja dari & karena \\
& kampung & kartar & strukturnya di \\
& Partisipasi & Partisipasi & masyarakat \\
& masyarakat & masyarakat & sebagai kartar dan \\
& dipengaruhi & dipengaruhi & PKK \\
& karena & karena & Partisipasi \\
& strukturnya bukan & strukturnya di & masyarakat \\
& sebagai pengurus & masyarakat & dipengaruhi \\
& kampung & sebagai kartar & karena \\
& & dan PKK & strukturnya di \\
& & & masyarakat \\
& & & sebagai kartar \\
\hline \hline
\end{tabular}

Sumber: Hasil analisis, 2018

Tabel 5.

Rekapitulasi Analisis untuk Harapan

\begin{tabular}{lll}
\hline \multicolumn{1}{c}{ Pemerintah } & \multicolumn{2}{c}{ Masyarakat } \\
\hline \multicolumn{1}{c}{ P1 } & P2 & \multicolumn{1}{c}{ M1 } \\
\hline Masyarakat & Masyarakat & Masyarakat memiliki \\
berpartisipasi & berpartisipasi karena & harapan untuk \\
karena memiliki & memiliki harapan untuk & kampungnya tidak \\
harapan untuk & menghidupkan kembali & berkembang, sehingga \\
mengembangkan & nilai-nilai yang ada & memperngaruhi \\
kampungnya & tanpa harus & partisipasinya \\
& mengkomersilkan & Masyarakat \\
& kampungnya & berpartisipasi karena \\
& Masyarakat memiliki & memiliki harapan untuk \\
& harapan untuk tidak & kampungnya memiliki \\
& mengkomersilkan & UKM sendiri \\
& Kampung Ketandan & \\
\hline \hline
\end{tabular}

Sumber: Hasil analisis, 2018

\section{1) Struktur sosial}

Struktur sosial dalam penelitian ini diartikan sebagai peran masyarakat Kampung Ketandan sebagai kampung wisata yang berada di tengah kota Surabaya. Berdasarkan hasil konten analisis, diketahui bahwa baik masyarakat ataupun pemerintah memberikan pernyataan yang mengindikasi bahwa struktur sosial dapat dikatakan berpengaruh terhadap kondisi partisipasi masyarakat Kampung Ketandan yang dapat dilihat pada Tabel 4. Masyarakat akan berpartisipasi jika memiliki peran sebagai pengurus kampung, anggota PKK ataupun sebagai karang taruna. Partisipasi masyarakat juga dipengaruhi dari bagaimana kinerja dari pengurus kampung ataupun karang taruna Kampung Ketandan. Dapat dikatakan bahwa semakin baik kinerja pengurus kampung, masyarakat akan memiliki keinginan berpartipasi yang semakin tinggi.

2) Harapan

Harapan yang dimaksudkan adalah keinginan atau harapan masyarakat untuk menjadikan Kampung Ketandan sebagai kampung wisata. Berdasarkan hasil analisis konten, faktor harapan dapat dikatakan berpengaruh terhadap partisipasi masyarakat Kampung Ketandan dikarenakan adanya penyataan baik dari pemerintah atau masyarakat yang mengindikasikan pengaruhnya. Dengan masyarakat memiliki harapan untuk kampungnya berubah menjadi lebih baik, dalam hal ini menjadi kampung wisata, masyarakat terlibat dalam kegiatan-kegiatan yang dilaksankan baik oleh pemerintah maupun pemuda karang taruna. Faktor ini memiliki pengaruh juga kepada masyarakat yang tidak menginginkan kampungnya menjadi kampung wisata, sehingga tidak adanya partisipasi yang diberikan. Berikut disajikan rekapitulasi hasil analisis keberpengaruhan harapan pada Tabel 5.

3) Pendidikan

Pendidikan yang dimaksudkan adalah latar belakang pendidikan dari masyarakat Kampung Ketandan. Berdasarkan hasil konten analisis, meski tiga dari empat responden tidak memberikan pernyataan mengenai latar belakang pendidikan, didapati responden dari pemerintah menyatakan bahwa latar belakang pendidikan tidak memengaruhi partisipasi masyarakat Kampung Ketandan untuk terlibat dalam berbagai kegiatan yang ada yang dapat dilihat pada Tabel 6 .

Tabel 6.

Rekapitulasi Analisis untuk Pendidikan

\begin{tabular}{llll}
\hline \multicolumn{2}{c}{ Rekapitulasi Analisis untuk Pendidikan } \\
\hline Pemerintah & \multicolumn{2}{c}{ Masyarakat } \\
\hline P1 & P2 & M1 & M2 \\
\hline $\begin{array}{l}\text { Partisipasi masyarakat tidak dipengaruhi } \\
\text { dari latar belakang pendidikan }\end{array}$ & & \\
\hline \hline Sumber: Hasil analisis, 2018 & & \\
Pumb & &
\end{tabular}

Tabel 7.

Rekapitulasi Analisis untuk Budaya Lokal

\begin{tabular}{|c|c|c|c|}
\hline \multicolumn{2}{|l|}{ Pemerintah } & \multicolumn{2}{|c|}{ Masyarakat } \\
\hline $\mathrm{P} 1$ & $\mathrm{P} 2$ & M1 & M2 \\
\hline $\begin{array}{l}\text { Partisipasi } \\
\text { masyarakat } \\
\text { dipengaruhi dari } \\
\text { kegiatan } \\
\text { keagamaan yang } \\
\text { ada }\end{array}$ & & $\begin{array}{l}\text { Partisipasi masyarakat } \\
\text { dipengaruhi dari kegiatan } \\
\text { seni-budaya yang ada }\end{array}$ & $\begin{array}{l}\text { Partisipasi } \\
\text { masyarakat } \\
\text { dipengaruhi dari } \\
\text { nilai-nilai } \\
\text { budaya yang } \\
\text { ada, }\end{array}$ \\
\hline $\begin{array}{l}\text { Partisipasi } \\
\text { masyarakat } \\
\text { dipengaruhi dari } \\
\text { nilai-nilai budaya } \\
\text { yang ada }\end{array}$ & & $\begin{array}{l}\text { Partisipasi masyarakat } \\
\text { dipengaruhi dari kegiatan } \\
\text { keagamaan yang ada } \\
\text { Partisipasi masyarakat } \\
\text { dipengaruhi dari } \\
\text { nilai-nilai budaya yang } \\
\text { ada, seperti gotong } \\
\text { royong, berkumpul } \\
\text { bersama, bermain } \\
\text { bersama dan lainnya }\end{array}$ & $\begin{array}{l}\text { seperti gotong } \\
\text { royong, } \\
\text { berkumpul } \\
\text { bersama, } \\
\text { bermain } \\
\text { bersama dan } \\
\text { lainnya }\end{array}$ \\
\hline
\end{tabular}

Sumber: Hasil analisis, 2018

Faktor budaya dalam penilitian merupakan nilai-nilai yang ada dimasyarakat, seperti gotong royong, saling bertegur sapa, berkumpul bersama, dan kegiatan lainnya yang masih dipertahankan masyarakat Kampung Ketandan yang diwujudkan pada cara hidup masyarakatnya. Dengan masih dijaganya budaya tersebut, faktor ini diujikan untuk melihat pengaruh adanya budaya di masyarakat terhadap kondisi partisipasi masyarakat Kampung Ketandan. Berdasarkan analisis hasil wawancara, didapati faktor budaya memengaruhi keterlibatan masyarakat Kampung Ketandan yang dapat dilihat pada Tabel 7. Hal tersebut dibuktikan dengan budaya lokal masyarakat memengaruhi keterlibatan masyarakat untuk 
mengikuti kegiatan-kegiatan, baik mewujudkan atraksi budaya maupun untuk menjaga kebersihan lingkungan.

\section{Ekonomi}

Ekonomi yang dimaksudkan adalah melihat pada jenis pekerjaan masyarakat Kampung Ketandan. Faktor ini diujikan untuk melihat pengaruh jenis perkerjaan, baik formal atau informal terhadap partisipasi masyarakat Kampung Ketandan sebagai kampung wisata. Berdasarkan hasil analisis, meskipun terdapat perbedaan anggapan dari pemerintah dan masyarakat, dapat disimpulkan bahwa jenis pekerjaan memengaruhi partisipasi masyarakat Kampung Ketandan yang dapat dilihat pada Tabel 8. Adanya perbedaan anggapan tersebut disebabkan oleh pemerintah yang menganggap jika jenis pekerjaan formal dengan jam kerja teratur membuat masyarakat akan memprioritaskan pekerjaannya. Sedangkan dari sudut pandang tokoh masyarakat, jenis pekerjaan tidak terindikasi berpengaruh kepada partisipasi masyarakat karena kegiatan yang diadakan untuk melibatkan partisipasi masyarakat diadakan diluar dari jam efektif kerja, sehingga seakan-akan jenis pekerjaan tidak memengaruhi partisipasi mereka.

Tabel 8.

Rekapitulasi Analisis untuk Pekerjaan

\begin{tabular}{llll}
\hline \hline \multicolumn{1}{c}{ Pemerintah } & \multicolumn{1}{c}{ P2 } & \multicolumn{1}{c}{ M1 } & \multicolumn{1}{c}{ M2 } \\
\hline Masyarakat & Masyarakat yang & Pekerjaan & Pekerjaan \\
Kampung & sudah memiliki & masyarakat & \multicolumn{1}{c}{ masyarakat } \\
Ketandan memiliki & UKM diarahkan & Kampung & Kampung \\
dinamika yang & untuk menjadi & Ketandan & Ketandan \\
tinggi berkenaan & pelopor bagi & tidak & tidak \\
dengan jenis & warga lainnya & memengaruhi & memengaruhi \\
pekerjaannya & & partisipasinya & partisipasinya \\
Partisipasi & Pekerjaan & & \\
masyarakat & masyarakat & & \\
dipengaruhi oleh & memengaruhi & & \\
jam kerja dari & waktu untuk & & \\
masyarakat & berpartisipasi & & \\
Kampung & & & \\
Ketandan & & & \\
\hline \hline Sumber: & & & \\
\hline
\end{tabular}

Tabel 9.

Rekapitulasi Analisis untuk Sarana Berkumpul dan Beratraksi

\begin{tabular}{|c|c|c|c|}
\hline \multicolumn{2}{|c|}{ Pemerintah } & \multicolumn{2}{|c|}{ Masyarakat } \\
\hline $\mathrm{P} 1$ & $\mathrm{P} 2$ & M1 & M2 \\
\hline $\begin{array}{l}\text { Adanya } \\
\text { sarana untuk } \\
\text { berkumpul } \\
\text { dan beratraksi } \\
\text { tidak } \\
\text { memengaruhi } \\
\text { partisipasi } \\
\text { masyarakat } \\
\text { Kampung } \\
\text { Ketandan }\end{array}$ & $\begin{array}{l}\text { Sarana } \\
\text { berkumpul dan } \\
\text { beratraksi di } \\
\text { Kampung } \\
\text { Ketandan } \\
\text { berupa joglo } \\
\text { memengaruhi } \\
\text { partisipasi } \\
\text { masyarakat } \\
\text { dengan } \\
\text { menggunakann } \\
\text { ya sebagai pusat } \\
\text { kegiatan }\end{array}$ & $\begin{array}{l}\text { Sarana berkumpul } \\
\text { dan beratraksi di } \\
\text { Kampung Ketandan } \\
\text { berupa joglo } \\
\text { memengaruhi } \\
\text { partisipasi } \\
\text { masyarakat dengan } \\
\text { menggunakannya } \\
\text { sebagai pusat } \\
\text { kegiatan } \\
\text { Sarana berkumpul } \\
\text { dan beratraksi di } \\
\text { Kampung Ketandan } \\
\text { berupa joglo } \\
\text { digunakan sebagai } \\
\text { pusat kegiatan }\end{array}$ & $\begin{array}{l}\text { Adanya ruang } \\
\text { publik joglo } \\
\text { digunakan } \\
\text { sebagai ruang } \\
\text { berkumpul } \\
\text { bagi } \\
\text { masyarakat } \\
\text { Kampung } \\
\text { Ketandan }\end{array}$ \\
\hline
\end{tabular}

Sumber: Hasil analisis, 2018

\section{Sarana}

Sarana yang dimaksudkan adalah sarana untuk berkumpul dan beratraksi bagi masyarakat Kampung Ketandan. Berdasarkan konten analisis yang dilakukan, didapati bahwa dari empat responden, tiga diantaranya menyebutkan adanya indikasi pengaruh sarana untuk berkumpul warga yang dalam hal ini berupa joglo terhadap partisipasi masyarakat Kampung Ketandan sebagai kampung wisata, yang dapat dilihat pada Tabel 9. Joglo yang digunakan sebagai pusat kegiatan warga Kampung Ketandan memberikan kemudahan warga untuk menerapkan nila-nilai budaya lokal serta menjadi salah satu daya tarik pula bagi wisatawan yang datang.

\section{E. Prasarana}

Berdasarkan hasil analisis, faktor prasarana merupakan faktor yang berpengaruh untuk masyarakat Kampung Ketandan berpartisipasi di kampungnya, yang dapat dilihat pada Tabel 10. Adanya perbaikan sarana berupa joglo, serta pemberian jaringan listrik yang mumpuni, membuat masyarakat lebih sering berkumpul dan dapat menggunakannya. Dengan kondisi jenis pekerjaan masyarakat di Kampung Ketandan yang mayoritas pada sektor informal, pemberian jaringan listrik yang mumpuni membantu mereka untuk bisa beraktivitas di joglo malam hari.

Tabel 10.

Rekapitulasi Analisis untuk Jaringan Listrik

\begin{tabular}{clcr}
\hline \hline \multicolumn{1}{c}{ Pemerintah } & \multicolumn{2}{c}{ Masyarakat } \\
\hline P1 & \multicolumn{1}{c}{ P2 } & M1 & M2 \\
\hline & Pemberian jaringan listrik pada joglo & & \\
& sebagai ruang publik memiliki pengaruh \\
pada partisipasi masyarakat Kampung & & \\
& Ketandan. & & \\
\hline \hline Sumber: Hasil analisis, 2018 &
\end{tabular}

\section{F. Lembaga}

Untuk faktor kelembagaan yang dimaksudkan adalah adanya pengaruh yang diberikan oleh lembaga pengelolaan terhadap partisipasi masyarakat Kampung Ketadan. Berdasar hasil wawancara, didapati bahwa pemerintah menyebutkan adanya pengaruh lembaga pengelola untuk kampung wisata, sehingga perlu dibentuknya lembaga khusus untuk mengelola Kampung Ketandan sebagai kampung wisata. Sedangkan menurut masyarakat, ada tidaknya lembaga masyarakat tidak memengaruhi partisipasi masyarakat Kampung Ketandan. Hal ini dikarenakan kondisi Kampung Ketandan yang masih dalam tahap perintisan, sehingga masyarakat mengganggap belum perlu untuk membentuk lembaga pengelola.

Perbedaan tersebut dikarenakan adanya fakta bahwa pemerintah menginginkan kampung wisata di Surabaya dapat menjadi seperti Kampung Maspatih yang memiliki pengelolaan mandiri oleh warganya. Sedangkan masyarakat Kampung Ketandan masih menganggap bahwa kampungnya bukan sebagai kampung wisata, melainkan sebagai kampung budaya saja. Dapat disimpulkan bahwa faktor kelembagaan adalah berpengaruh pada partisipasi masyarakat kedepannya dalam pengembangan kampung wisata yang dapat dilihat pada Tabel 11. 
Tabel 11.

Rekapitulasi Analisis untuk Lembaga Pengelola

\begin{tabular}{|c|c|c|c|}
\hline \multicolumn{2}{|l|}{ Pemerintah } & \multicolumn{2}{|r|}{ Masyarakat } \\
\hline P1 & P2 & M1 & M2 \\
\hline $\begin{array}{l}\text { Lembaga pengelola akan } \\
\text { memengaruhi partisipasi } \\
\text { masyarakat jika dibentuk. }\end{array}$ & & & $\begin{array}{l}\text { Lembaga pengelola tidak } \\
\text { memengaruhi partisipasi } \\
\text { masyarakat Kampung } \\
\text { Ketandan. }\end{array}$ \\
\hline
\end{tabular}

Sumber: Hasil analisis, 2018

\section{G. Pemerintah}

Faktor pemerintah yang dimaksudkan adalah peran pemerintah dalam menjadikan Kampung Ketandan sebagai kampung wisata yang dilihat dari bentuk pelayanan serta apresiasi yang diberikan di Kampung Ketandan. Pemerintah sebagai subjek yang menetapkan Kampung Ketandan sebagai kampung wisata telah membuat masyarakat ikut berpartisipasi dalam menciptakan kampung wisata, yaitu dengan pada kegiatan pemberian tanaman, pembaharuan fisik kampung baik jaringan jalan, jaringan drainase, maupun kegiatan pengecatan mural di Kampung Ketandan. Partisipasi masyarakat pun mulai berkembang dengan adanya kegiatan-kegiatan eventual yang diselenggarakan pemerintah, sehingga pelayanan pemerintah terindikasi berpengaruh terhadap partisipasi masyarakat Kampung Ketandan yang dapat dilihat pada Tabel 12 .

Tabel 12.

Rekapitulasi Analisis untuk Pelayanan Pemerintah

\begin{tabular}{lll}
\hline \hline \multicolumn{1}{c}{ P1 } & \multicolumn{1}{c}{ P2 } & Masyarakat \\
\hline Pemerintah & Adanya & \multicolumn{1}{c}{ M2 } \\
memberikan & pelayanan & Pemerintah \\
arahan kepada & pemerintah & memberikan \\
masyarakat & sebagai & berupa \\
dalam hal & penggerah serta & tanaman-tana \\
kebersihan & memiliki & man, \\
kampung, & kekuatan & pengecatan \\
perwujudan & koordinasi & mural, \\
atraksi di & yang & penertiban \\
kampung, serta & menyeluruh & secara \\
memberikan & memengaruhi & menyeluruh \\
berbaikan untuk & partisipasi & dari \\
joglo dan kondisi & masyarakat & kelurahan/ \\
fisik Kampung & Pemerintah & kecamatan \\
Ketandan & memperkenalk & \\
Adanya & an Kampung & \\
pelayanan & Ketandan & \\
pemerintah & kepada delegasi & \\
sebagai & saat Prepcom 3 & \\
penggerah serta & digelar di & \\
memiliki & Surabaya & \\
kekuatan & Pemerintah & \\
koordinasi yang & menyediakan & \\
menyeluruh & pelatihan untuk & \\
memengaruhi & menjadi & \\
partisipasi & kampung & \\
masyarakat & wisata & \\
& & \\
\hline \hline
\end{tabular}

Sumber: Hasil analisis, 2018

Selain pelayanan pemerintah, masyarakat menganggap bahwa adanya perhatian dan kepercayaan pemerintah kepada masyarakat Kampung Ketandan dianggap sebagai sebuah apresiasi yang memengaruhi partisipasi masyarakat dari pemerintah yang dapat dilihat pada Tabel 13. Adanya anggapan tersebut pun membuat partisipasi masyarakat mulai berkembang. Salah satu contonya masyarakat diberikan kesempatan untuk ikut serta dalam setiap kegiatan 'Mlaku-mlaku Nang Tunjungan', yang menjadi agenda rutin pemerintah, berupa stan berjualan yang dimanfaatkan masyarakat untuk menjual hasil UKM yang di ada di Kampung Ketandan.

Tabel 13.

Rekapitulasi Analisis untuk Apresiasi Pemerintah

\begin{tabular}{|c|c|c|c|}
\hline \multicolumn{2}{|l|}{ Pemerintah } & \multicolumn{2}{|c|}{ Masyarakat } \\
\hline $\mathrm{P} 1$ & $\mathrm{P} 2$ & M1 & M2 \\
\hline $\begin{array}{l}\text { Adanya apresiasi } \\
\text { dari pemerintah } \\
\text { berupa } \\
\text { perhatiannya } \\
\text { kepada } \\
\text { Kampung }\end{array}$ & & $\begin{array}{l}\text { Pemerintah memberikan } \\
\text { bantuan berupa stand jualan } \\
\text { kepada masyarakat } \\
\text { Kampung Ketandan untuk } \\
\text { event di Jalan Tunjungan }\end{array}$ & $\begin{array}{l}\text { Pemerintah } \\
\text { merealisasikan } \\
\text { harapan } \\
\text { masyarakat } \\
\text { Kampung } \\
\text { Ketandan }\end{array}$ \\
\hline Ketandan & & $\begin{array}{l}\text { Perhatian dan kepercayaan } \\
\text { pemerintah yang dianggap } \\
\text { sebagai apresiasi } \\
\text { menyebakan banyak orang } \\
\text { mengenal Kampung } \\
\text { Ketandan, } \\
\text { Bentuk perhatian } \\
\text { pemerintah kepada } \\
\text { Kampung Ketandan } \\
\text { dianggap sebagai apresiasi } \\
\text { dari pemerintah }\end{array}$ & $\begin{array}{l}\text { Masyarakat } \\
\text { menginginkan } \\
\text { apresiasi dari } \\
\text { pemerintah } \\
\text { untuk } \\
\text { membangun } \\
\text { kampung wisata }\end{array}$ \\
\hline
\end{tabular}

Sumber: Hasil analisis, 2018

\section{H. Faktor baru}

Dari hasil wawancara baik dengan pemerintah maupun masyarakat, ditemukan faktor baru yang memengaruhi partisipasi masyarakat Kampung Ketandan. Faktor temuan ini dianggap sebagai faktor lokal dari masyarakat Kampung Ketandan yang memengaruhi partisipasinya menjadikan Kampung Ketandan sebagai kampung wisata. Faktor yang dimaksud adalah faktor pendapatan, faktor penggerak, faktor karakter masyarakat, dan faktor moral.

1) Pendapatan

Tabel 14.

Rekapitulasi Analisis untuk Pendapatan

\begin{tabular}{|c|c|c|c|}
\hline \multicolumn{2}{|l|}{ Pemerintah } & \multicolumn{2}{|c|}{ "Masyarakat } \\
\hline P1 & $\mathrm{P} 2$ & M1 & M2 \\
\hline $\begin{array}{l}\text { Pemerintah menyebutkan ada tidaknya pendapat } \\
\text { memengaruhi partisipasi masyarakat, seperti di } \\
\text { Kampung Maspatih. }\end{array}$ & & & \\
\hline
\end{tabular}

Faktor pendapatan merupakan faktor temuan dari hasil konten analisis sebagai faktor yang memengaruhi kondisi partisipasi masyarakat Kampung Ketandan yang dapat dilihat pada Tabel 14. Faktor ini dinyatakan oleh pemerintah yang diikuti dengan keinginan adanya pendapatan yang akan diperoleh masyarakat dari partisipasinya mewujudkan Kampung Ketandan menjadi kampung wisata. Dari hasil analisis serta melihat adanya kesamaan karakter dari variabel pendapatan dengan sub-faktor pekerjaan, maka variabel ini dapat dikategorikan dalam faktor ekonomi sebagai sub-faktor yang memengaruhi partisipasi masyarakat Kampung Ketandan dalam mewujudkan kampung wisata. 


\section{2) Penggerak}

Faktor penggerak merupakan faktor temuan dari hasil konten analisis sebagai faktor yang memengaruhi kondisi partisipasi masyarakat Kampung Ketandan. Dari hasil analisis, faktor ini dinyatakan oleh pemerintah dan masyarakat bahwa pengembangan kampung memerlukan adanya sosok penggerak yang datang dari masyarakat yang dapat dilihat pada Tabel 15. Pemerintah menganggap bahwa adanya penggerak yang muncul dari masyarakat akan memilki peranan penting dalam peningkatan partisipasi masyarakat Kampung Ketandan sebagai kampung wisata. Masyarakat juga menyatakan bahwa tidak adanya penggerak yang muncul dari masyarakat membuat masyarakat kurang berani untuk menunjukkan kampungnya ke luar. Melihat hal tersebut serta adanya kesamaan karakter dari variabel penggerak dengan sub-faktor pada faktor sosial, maka variabel ini dapat dikategorikan dalam faktor sosial sebagai sub-faktor yang memengaruhi partisipasi masyarakat Kampung Ketandan dalam mewujudkan kampung wisata.

Tabel 15.

Rekapitulasi Analisis untuk Penggerak

\begin{tabular}{lll}
\hline \hline \multicolumn{1}{c}{ Pemerintah } & \multicolumn{1}{c}{ P2 } & M1 \\
\hline \multicolumn{1}{c}{ P1 } & \multicolumn{1}{c}{ P2 } & \multicolumn{1}{c}{ M2 } \\
\hline Pemerintah & Tidak adanya & Tidak adanya \\
menyatakan bahwa & penggerak di & penggerak yang \\
penggerak di suatu & Kampung & dapat membawa \\
kampung penting & Ketandan & kampung ke luar \\
adanya & dibandingkan & \\
& dengan Kampung & \\
& Maspatih & \\
\hline \hline
\end{tabular}

Sumber: Hasil analisis, 2018

\section{3) Faktor Karakter Masyarakat}

Faktor karakter masyarakat merupakan faktor temuan dari hasil konten analisis sebagai faktor yang memengaruhi kondisi partisipasi masyarakat Kampung Ketandan. Dari hasil analisis, responden dari masyarakat menganggap bahwa adanya karakter masyarakat yang cepat bosan terhadap sesuatu yang bersifat rutin serta kurangnya rasa percaya diri adalah kendala yang harus dihadapi Kampung Ketandan, yang dapat dilihat pada Tabel 16. Disisi lain, karakter masyarakat yang tidak memerlukan apresiasi pada setiap partisipasi dapat menjadi potensi masyarakat Kampung Ketandan dalam mewujudkan kampungnya sebagai kampung wisata. Melihat hal tersebut serta adanya kesamaan karakter dari variabel karakter masyarakat dengan sub-faktor pada faktor sosial, maka variabel ini dapat dikategorikan dalam faktor sosial sebagai sub-faktor yang memengaruhi partisipasi masyarakat Kampung Ketandan dalam mewujudkan kampung wisata.

Tabel 16.

Rekapitulasi Analisis untuk Karakter Masyarakat

\begin{tabular}{|c|c|c|}
\hline Pemerintah & & Masyarakat \\
\hline P2 & M1 & M2 \\
\hline & & $\begin{array}{l}\text { Adanya karakter di masyarakat yang cepat bosan } \\
\text { dengan kegiatan yang bersifat rutin }\end{array}$ \\
\hline & & $\begin{array}{l}\text { Adanya rasa kurang percaya diri di masyarakat } \\
\text { Kampung Ketandan untuk bisa tampil menjadi } \\
\text { kampung wisata }\end{array}$ \\
\hline & & $\begin{array}{l}\text { Untuk melakukan kegiatan kerja bakti } \\
\text { yang diadakan pengurus kampung, warga } \\
\text { tidak memerlukan apresiasi }\end{array}$ \\
\hline
\end{tabular}

Sumber: Hasil analisis, 2018

4) Moral

Tabel 17.

Rekapitulasi Analisis untuk Moral

\begin{tabular}{ccc}
\hline \hline \multicolumn{1}{c}{ Pemerintah } & \multicolumn{1}{c}{ Masyarakat } \\
\hline P1 & P2 & M1 \\
\hline $\begin{array}{l}\text { Adanya pemahamn } \\
\text { dimasyarakat untuk }\end{array}$ & $\begin{array}{l}\text { Masyarakat memiliki tanggung } \\
\text { maju }\end{array}$ & $\begin{array}{l}\text { jawab moral untuk memajukan } \\
\text { kampung }\end{array}$ \\
\hline \hline
\end{tabular}

Sumber: Hasil analisis, 2018

Tabel 18.

Faktor yang Memengaruhi Partisipasi Masyarakat Kampung Ketandan sebagai Kampung Wisata

\begin{tabular}{|c|c|c|}
\hline Indikator & $\begin{array}{l}\text { Variabel } \\
\text { Berpengaruh }\end{array}$ & Keterangan \\
\hline Faktor & Struktur & Kondisi eksisting partisipasi masyarakat \\
\hline \multirow[t]{5}{*}{ Sosial } & Sosial & $\begin{array}{l}\text { Kampung Ketandan dipengaruhi oleh } \\
\text { struktur sosial dari tiap masyarakat dan } \\
\text { harapan atau keinginan masyarakat untuk } \\
\text { kampungnya menjadi kampung wisata }\end{array}$ \\
\hline & Harapan & $\begin{array}{l}\text { Masyarakat membutuhkan sosok penggerak } \\
\text { untuk menciptakan partisipasi yang lebih } \\
\text { lanjut }\end{array}$ \\
\hline & Penggerak & Terdapat karakter lokal masyarakat yang \\
\hline & $\begin{array}{l}\text { Karakter } \\
\text { Masyarakat }\end{array}$ & $\begin{array}{l}\text { memiliki pengaruh kepada partisipasi yang } \\
\text { diberikan }\end{array}$ \\
\hline & Moral & $\begin{array}{l}\text { Terdapat nilai moral masyarakat yang } \\
\text { memiliki pengaruh kepada partisipasi yang } \\
\text { lebih lanjut }\end{array}$ \\
\hline Faktor & Budaya Lokal & Kondisi eksisting partisipasi masyarakat \\
\hline Budaya & & $\begin{array}{l}\text { Kampung Ketandan dipengaruhi oleh budaya } \\
\text { lokal yang masih dijaga oleh masyarakat }\end{array}$ \\
\hline \multirow[t]{2}{*}{$\begin{array}{l}\text { Faktor } \\
\text { Ekonomi }\end{array}$} & Pekerjaan & $\begin{array}{l}\text { Kondisi eksisting partisipasi masyarakat } \\
\text { Kampung Ketandan dipengaruhi oleh jenis } \\
\text { pekerjaan yang ada di masyarakat yang juga } \\
\text { menyebabkan kegiatan partisipasi terbatas } \\
\text { pada waktu diluar waktu kerja (formal) }\end{array}$ \\
\hline & Pendapatan & $\begin{array}{l}\text { Masyarakat membutuhkan pendapatan pada } \\
\text { kegiatan partisipasi yang diberikan }\end{array}$ \\
\hline Faktor & Saran & Kondisi eksisting partisipasi masyarakat \\
\hline Sarana & $\begin{array}{l}\text { berkumpul } \\
\text { dan beratraksi }\end{array}$ & $\begin{array}{lrrr}\text { Kampung } & \text { Ketandan } & \text { dipengaruhi } & \text { oleh } \\
\text { ketersediaan rarana } & \text { berkumpul } & \text { dan } \\
\text { beratraksi berupa joglo } & & \end{array}$ \\
\hline Faktor & Jaringan & Kondisi eksisting partisipasi masyarakat \\
\hline Prasarana & listri & $\begin{array}{l}\text { Kampung Ketandan dipengaruhi oleh adanya } \\
\text { jaringan listrik yang disediakan di joglo }\end{array}$ \\
\hline $\begin{array}{l}\text { Faktor } \\
\text { Kelembaga } \\
\text { an }\end{array}$ & $\begin{array}{l}\text { Lembaga } \\
\text { pengelola }\end{array}$ & $\begin{array}{l}\text { Masyarakat membutuhkan lembaga } \\
\text { pengelola wisata, untuk menciptakan } \\
\text { partisipasi yang lebih lanjut }\end{array}$ \\
\hline Faktor & $\mathrm{Pe}$ & Kondisi eksisting partisipasi masyarakat \\
\hline \multirow[t]{2}{*}{$\begin{array}{l}\text { Pemerin } \\
\text { tah }\end{array}$} & & $\begin{array}{l}\text { Kampung Ketandan dipengaruhi oleh peran } \\
\text { pemerintah dalam memberikan layanan } \\
\text { bantuan pembangunan fisik kampung serta } \\
\text { adanya bentuk apresiasi yang telah diberikan }\end{array}$ \\
\hline & $\begin{array}{l}\text { Apresiasi } \\
\text { pemerintah } \\
\text { Variabel }\end{array}$ & \\
\hline Indikator & $\begin{array}{l}\text { Tidak } \\
\text { Berpengaruh }\end{array}$ & Keterangan \\
\hline $\begin{array}{l}\text { Faktor } \\
\text { Sosial }\end{array}$ & Pendidikan & $\begin{array}{l}\text { Partisipasi masyarakat Kampung Ketandan } \\
\text { tidak dipengaruhi oleh latar belakang } \\
\text { pendidikan masyarakat dikarenakan } \\
\text { masyarakat beranggapan bahwa untuk } \\
\text { berpartisipasi tidak memerlukan kondisi latar } \\
\text { belakang pendidikan }\end{array}$ \\
\hline
\end{tabular}

Sumber: Hasil analisis, 2018

Faktor moral merupakan faktor temuan dari hasil konten analisis sebagai faktor yang memengaruhi kondisi partisipasi masyarakat Kampung Ketandan. Dari hasil analisis, faktor ini 
dinyatakan oleh pemerintah dan masyarakat bahwa setelah adanya pembangunan joglo, masyarakat memiliki tanggung jawab untuk memajukan Kampung Ketandan dengan cara menghidupkan dan menyelenggarakan kegiatan di joglo, yang dapat dilihat pada Tabel 17. Melihat hasil analisis diatas serta adanya kesamaan karakter dari variabel moral dengan sub-faktor pada faktor sosial, maka variabel ini dapat dikategorikan dalam faktor sosial sebagai sub-faktor yang memengaruhi partisipasi masyarakat Kampung Ketandan dalam mewujudkan kampung wisata.

Tabel 8 merupakan hasil analisis faktor yang memengaruhi partisipasi masyarakat Kampung Ketandan sebagai kampung wisata.

\section{KESIMPULAN}

Kampung Ketandan sebagai kampung wisata di tahap perintisan memiliki kondisi tingkat partisipasi eksisting masyarakat yang dipengaruhi oleh faktor sosial, faktor budaya, faktor ekonomi, faktor sarana, faktor prasarana, faktor kelembagaan serta faktor pemerintah. Hasil analisis menyebutkan adanya identifikasi ini dapat dijadikan sebagai masukan dalam meningkatkan partisipasi masyarakat Kampung Ketandan untuk pengembangannya sebagai kampung wisata. Ditemukannya faktor baru sebagai faktor lokal pengaruh partisipasi masyarakat menandakan masih adanya kendala partisipasi masyarakat dari segi karakter masyarakat, tidak adanya penggerak serta belum sadarnya masyarakat bahwa terdapat potensi sumber pendapatan pada kegiatan wisata yang berlangsung di Kapung Ketandan.

\section{DAFTAR PUSTAKA}

[1] S. Widiastuti and N. Yuliastuti, "Lingkungan Kampung Berkelanjutan dan Potensi Masyarakat di Kampung Kanalsari, Semarang Indonesia," Maj. Tek. FT Univ. Diponegoro, vol. 33, no. 2, pp. 46-111, 2012.

[2] Koentjaraningrat, Pengantar Ilmu Antropologi. Jakarta: Rineka Cipta, 1990.

[3] Bappeko Surabaya, "Draft Rencana Induk Pengembangan Pariwisata Daerah Kota Surabaya," Surabaya, 2017.

[4] Bappeko Surabaya, "Rencana Detail Tata Ruang kota Unit Pengembangan Tunjungan Tahun 2011-2031," Surabaya, 2011.

[5] A. Fahrudin, Pemberdayaan Partisipasi dan Penguatan Masyarakat. Bandung: Humaniora, 2011.

[6] Soetomo, Pembangunan Masyarakat. Yogyakarta: Pustaka Pelajar, 2009. 